Article

\title{
Reduction and Nitridation of Iron/Vanadium Oxides by Ammonia Gas: Mechanism and Preparation of FeV45N Alloy
}

\author{
Yongjie Liu ${ }^{1}$, Yue Wang ${ }^{1}$, Zhixiong You ${ }^{1,2, *}$ and Xuewei Lv ${ }^{1,2}$ \\ 1 College of Materials Science and Engineering, Chongqing University, Chongqing 400044, China; \\ liuyongjie@cqu.edu.cn (Y.L.); wangyue_cqu@163.com (Y.W.); lvxuewei@163.com (X.L.) \\ 2 Chongqing Key Laboratory of Vanadium-Titanium Metallurgy and Advanced Materials, \\ Chongqing University, Chongqing 400044, China \\ * Correspondence: youzx@cqu.edu.cn; Tel.: +86-183-0608-9886
}

Received: 16 January 2020; Accepted: 6 March 2020; Published: 9 March 2020

\begin{abstract}
The steel micro-alloyed with ferrovanadium nitride has extremely superior properties that make it widely utilized in structural components, construction and aircraft. The conventional methods for synthesizing ferrovanadium nitride include nitridation of pure ferrovanadium alloy or carbothermal nitridation of metallic oxides, using nitrogen or ammonia gas as nitrogen sources. In this study, ferrovanadium nitride $(\mathrm{FeV} 45 \mathrm{~N})$ was prepared by direct reduction and nitridation of the corresponding metal oxides with ammonia as the reductant and nitrogen source. This method avoids the introduction of other impurity elements, except the negligible trace elements accompanied with the raw materials. The thermodynamics of the reduction and nitridation process were initially analyzed. During the subsequent ammonia reduction process, the FeV45N powders were successfully obtained at $1273 \mathrm{~K}$ for $6 \mathrm{~h}$. The obtained powders were pressed into cylindrical briquettes by hot pressing (HP) at $1473 \mathrm{~K}$ for $1 \mathrm{~h}$ in vacuum. In the investigation, the $\mathrm{X}$-ray diffraction and morphological analysis of the products was also carried out, and the reaction mechanisms were discussed in detail. The nitrogen content of the final product can reach $11.85 \mathrm{wt}$. \%, and the residual oxygen content can be reduced to $0.25 \mathrm{wt}$. \%. By sintering, the density of the alloy can reach $5.92 \mathrm{~g} / \mathrm{cm}^{3}$.
\end{abstract}

Keywords: ferrovanadium nitride; ammonia gas; reduction; nitridation; mechanism

\section{Introduction}

Recently, high-strength low-alloy (HSLA) steel has attracted much attention in industry due to its superior properties and economic benefits [1-3]. The superior performance of HSLA steel mainly accounts for microalloying with carbide- and nitride-forming metals $(\mathrm{V}, \mathrm{Nb}, \mathrm{Al}, \mathrm{Ti}$, etc.). The advantages of nitrogen are related to grain refinement, austenite stabilization, formation of nitrides and carbonitrides with extremely high structural hardness and significant increasing of strength, without restriction of ductility [3,4]. Among these microalloying additives, HSLA steel microalloyed with vanadium and nitrogen exhibits particular economic superiority.

During steel making, vanadium can be added by means of V-bearing compounds-ferrovanadium $(\mathrm{FeV})$, vanadium carbide $(\mathrm{VC})$, vanadium silicide $\left(\mathrm{V}_{3} \mathrm{Si}\right)$, etc. However, the drawback of these additives is the absence of nitrogen. Although nitrogen is capable of being introduced into the melt by blowing $\mathrm{N}$-bearing gases, the final composition of the melt is generally corrected by adding $\mathrm{N}$-bearing alloys. Up to now, various alloys, including vanadium nitride $(\mathrm{VN})$, vanadium carbonitride $(\mathrm{V}(\mathrm{C}, \mathrm{N}))$ and ferrovanadium nitride ( $\mathrm{FeVN})$, have been proposed for the combined introduction of vanadium and nitrogen into the molten steel [5-9]. Vanadium carbonitride has been researched for many years; however, its practical use is inhibited by its low briquette density $\left(\approx 3 \mathrm{~g} / \mathrm{cm}^{3}\right)$ and high melting point 
( $>2673 \mathrm{~K})$. Compared with vanadium nitride, ferrovanadium nitride has better affinity and higher density $\left(>5 \mathrm{~g} / \mathrm{cm}^{3}\right)$, which makes it more easily absorbed by molten steel and can increase the recovery of vanadium and nitrogen, thereby reducing the production cost and improving the mechanical properties of the steel $[10,11]$.

Traditionally, ferrovanadium nitride could be synthesized by direct nitridation of ferrovanadium alloy, carbothermal reduction-nitridation or hydrogen-based reduction-nitridation of corresponding metallic oxides, using nitrogen or ammonia gas as nitrogen sources. The current methods are classified as solid nitridation, liquid nitridation, sintering processes, plasma smelting and carbothermal reduction-nitridation [1,12-21]. Grishchenko et al. have synthesized ferrovanadium nitride using ferrovanadium as raw material via roasting at $1327 \mathrm{~K}$ in a vacuum furnace for about $17 \mathrm{~h}$ [12]. Nevertheless, the nitrogen content of the final product was $5.0-6.6 \%$ and was characterized as heterogeneous. Franke et al. conducted similar experiments, whose results also proved that the $\mathrm{N}$ content could not meet the requirements of industrial production [13]. The study by Krastev indicated that the nitrogen content could be improved with the increase of temperature and reaction time, and by using a finer particle size [14]. Preparation of ferrovanadium nitride by liquid nitridation greatly shortened the reaction time [15]. However, the nitridation of liquid alloys has not been industrially adopted due to the high viscosity of nitrides-bearing ferrovanadium melts, which resulted in low nitrogen content in the melts. Ziatdinov et al. also synthesized ferrovanadium nitride from ferrovanadium powders by the self-propagation high-temperature synthesis (SHS) method [16]. Ferrovanadium nitride can also be prepared by the plasma smelting method using ferrovanadium alloys under a nitrogen atmosphere [17]. With respect to the above four methods, ferrovanadium was used as the raw material, which not only contained impurities ( $\mathrm{Al}, \mathrm{Si})$ but also consumed relatively more money and energy. Carbothermal reduction-nitridation of iron and vanadium oxides has also been investigated to prepare ferrovanadium nitride $[19,20]$. During the process, although $\mathrm{Al}, \mathrm{Si}$ impurities were not introduced, there was still some residual carbon in the final product, and the roasting temperature was very high (more than $1823 \mathrm{~K}$ ). Excessive reducing agent was always added to enhance the deoxidation process, which inevitably increased the residual carbon content and correspondingly decreased the nitrogen content in the product.

In recent decades, transition metal nitrides (TiN, $\mathrm{VN}, \mathrm{CrN}$, etc.) have been prepared from corresponding oxides using ammonia as nitrogen source and reducing agent [22-29]. Ammonia gas is proved to be more effective in the nitridation process than high-purity $\mathrm{N}_{2}$ gas [30]. In view of that superiority, ferrovanadium nitride was also expected to be synthesized by reduction and nitridation of a mixture of vanadium and iron oxides [31]. In the present study, ferrovanadium nitride $(\mathrm{FeV} 45 \mathrm{~N})$ was prepared by the specified process with ammonia gas. A systematic study on the thermodynamics of the $\mathrm{NH}_{3}-\mathrm{VO}_{2}-\mathrm{Fe}_{2} \mathrm{O}_{3}$ system was performed first. The phase transformation of vanadium and iron dioxides was studied using $\mathrm{X}$-ray diffraction. Subsequently, the obtained powders were sintered into bulk ferrovanadium nitride by hot pressing (HP). Morphological analysis of the product was also carried out, allowing the study to be concluded with a discussion of the applicable reaction mechanisms. Compared with the carbothermal reduction nitridation method, this method, using ammonia as the reductant and nitrogen source, avoided the introduction of carbon. Furthermore, the final product contained a relatively high nitrogen content and a low residual oxygen content.

\section{Experimental}

\subsection{Experimental Procedure}

Vanadium dioxide powder (Tiantian Chemical Reagent Company, Jiangsu, China, $\mathrm{VO}_{2},>99.7$ wt. \%) and $\mathrm{Fe}_{2} \mathrm{O}_{3}$ (Aladdin Industrial Corporation, Shanghai, China, >99.7 wt. \%) were used as raw materials to synthesis FeV45N. The particle sizes of these two materials were less than $74 \mu \mathrm{m}$. Theoretically, the iron and vanadium contents in $\mathrm{FeV} 45 \mathrm{~N}$ are about $45 \mathrm{wt}$. \% and $45 \mathrm{wt}$. \%, respectively. Thus, in order to synthesize $\mathrm{FeV} 45 \mathrm{~N}, 200 \mathrm{mg}$ of $\mathrm{Fe}_{2} \mathrm{O}_{3}$ and $220 \mathrm{mg}$ of $\mathrm{VO}_{2}$ were uniformly mixed and loaded onto an 
ultra-fine stainless steel mesh, which was supported by a corundum crucible. The steel mesh was used to obtain a porous structure, to ensure that ammonia gas was able to flow through the bottom of the anatase powder. Before the experiment, argon gas (99.999 vol.\%) flow of $150 \mathrm{~mL} / \mathrm{min}$ was introduced into an electric tube furnace to expel oxygen and moisture. This gas flow was maintained until the furnace was heated to the required temperature, through steps of $10 \mathrm{~K} / \mathrm{min}$. The crucible loading with the mixture was then placed in the roasting zone of the horizontal furnace tube, and the gas was switched to $\mathrm{NH}_{3}$ (99.999 vol.\%), which was also maintained at $150 \mathrm{~mL} / \mathrm{min}$. The sample was reduced and nitrided isothermally at temperatures of $873-1273 \mathrm{~K}$ for $1-6 \mathrm{~h}$. Once roasting was completed, the furnace was allowed to cool down under flowing argon gas. After that, the obtained powders were pressed into a cylindrical briquette $(10 \mathrm{~mm}$ in diameter, $4 \mathrm{~mm}$ in thickness) by hot pressing (HP) at $1473 \mathrm{~K} \mathrm{for} 1 \mathrm{~h}$ in vacuum.

\subsection{Analytical Method}

Thermodynamic analysis was conducted by using FactSage 6.2 based on the pure substances database [32,33]. After reaction, the cooled powders were examined by X-ray powder diffraction (Rigaku D/max 2500, Rigaku, Tokyo, Japan) under the conditions as follows: $\mathrm{Cu} \mathrm{K} \alpha$, tube current and voltage: $250 \mathrm{~mA}, 40 \mathrm{kV}$, scanning range: $10-90^{\circ}(2 \theta)$, step size: $0.02^{\circ}(2 \theta)$ and scanning speed: $8 \% \mathrm{~min}$. The oxygen and nitrogen contents of powders was tested by the German Eltra On-900 (German Eltra, Shanghai, China) N/O elemental analyzer. The sample was heated and fused in an ink crucible. The oxygen in the sample reacted with carbon to form carbon monoxide, and nitrogen was released in the elemental state. Scanning electron microscopy (JSM-7800F, Tokyo, Japan) was carried out to monitor overall powder morphology, and the microstructure of bulk ferrovanadium nitride. The density of the FeV45N briquette was measured using the Archimedes method (GB/T1423-1996).

\section{Thermodynamic Analysis}

In this work, $\mathrm{NH}_{3}$ contributed simultaneously as the reduction and the nitridation agent to react with the mixture of $\mathrm{Fe}_{2} \mathrm{O}_{3}$ and $\mathrm{VO}_{2}$. To predict the predominant field of various products, the equilibrium calculations of the $\mathrm{Fe}_{2} \mathrm{O}_{3}-\mathrm{NH}_{3}$ system and the $\mathrm{VO}_{2}-\mathrm{NH}_{3}$ system were performed, respectively. Figure 1 shows the solid phase fields calculated in the temperature range of $673-1573 \mathrm{~K}$ at a pressure of 1 bar. The input $\mathrm{NH}_{3}$ mole fraction was given as $n_{\mathrm{NH} 3} /\left(n_{\mathrm{NH} 3}+n_{\mathrm{Fe} 2 \mathrm{O} 3}\right)$ and $n_{\mathrm{NH} 3} /\left(n_{\mathrm{NH} 3}+n_{\mathrm{VO} 2}\right)$, where $n_{\mathrm{NH} 3}, n_{\mathrm{Fe} 2 \mathrm{O} 3}$ and $n_{\mathrm{VO} 2}$ represent the input mole numbers of $\mathrm{NH}_{3}, \mathrm{Fe}_{2} \mathrm{O}_{3}$ and $\mathrm{VO}_{2}$, respectively.

As shown in Figure $1 \mathrm{a}$, the solid phases, including $\mathrm{Fe}_{2} \mathrm{O}_{3}, \mathrm{Fe}_{3} \mathrm{O}_{4}, \mathrm{FeO}$ and $\mathrm{Fe}$, were mainly dependent on temperature and input $\mathrm{NH}_{3}$ fraction. The condition for the occurrence of Fe was that the temperature was about $823 \mathrm{~K}$ and the input $\mathrm{NH}_{3}$ fraction was about 0.5 . Thermodynamically, $\mathrm{Fe}_{2} \mathrm{O}_{3}$ can be easily reduced even at very low temperature and $\mathrm{NH}_{3}$ fraction. The reaction path of $\mathrm{Fe}_{2} \mathrm{O}_{3}$ varied as $\mathrm{Fe}_{2} \mathrm{O}_{3} \rightarrow \mathrm{Fe}_{3} \mathrm{O}_{4} \rightarrow \mathrm{FeO} \rightarrow \mathrm{Fe}$ or $\mathrm{Fe}_{2} \mathrm{O}_{3} \rightarrow \mathrm{Fe}_{3} \mathrm{O}_{4} \rightarrow \mathrm{Fe}$, which depended on the temperature. It is worthy to note that iron nitride was not observed in Figure 1a under the calculated conditions. As shown in Figure $1 \mathrm{~b}, \mathrm{VO}_{2}$ can be easily reduced to $\mathrm{V}_{2} \mathrm{O}_{3}$ at a temperature above $973 \mathrm{~K}$, regardless of $\mathrm{NH}_{3}$ fraction. When the temperature was lower than $973 \mathrm{~K}$, some $\mathrm{V}_{3} \mathrm{O}_{5}$ would have appeared and then been reduced to $\mathrm{V}_{2} \mathrm{O}_{3}$. It meant the reaction path of $\mathrm{VO}_{2}$ followed $\mathrm{VO}_{2} \rightarrow \mathrm{V}_{2} \mathrm{O}_{3} \rightarrow \mathrm{VN}$ or $\mathrm{VO}_{2} \rightarrow \mathrm{V}_{3} \mathrm{O}_{5} \rightarrow \mathrm{V}_{2} \mathrm{O}_{3} \rightarrow \mathrm{VN}$ at a different temperature range. However, the $\mathrm{NH}_{3}$ fraction required for reduction and nitridation of $\mathrm{V}_{2} \mathrm{O}_{3}$ was relatively higher, which should be greater than 0.98 . Thus, compared with Figure $1 \mathrm{a}$, when $\mathrm{Fe}_{2} \mathrm{O}_{3}$ was converted to $\mathrm{Fe}, \mathrm{VO}_{2}$ oxide was converted to $\mathrm{VN}$. At the same time, the generated iron can promote the decomposition of ammonia and affect the formation of vanadium nitride [34].

In order to predict the phase composition of $\mathrm{NH}_{3}-\mathrm{Fe}_{2} \mathrm{O}_{3}-\mathrm{VO}_{2}$ system, the solid phase composition as a function of input $\mathrm{NH}_{3}$ mole fraction at $1273 \mathrm{~K}$ was calculated. The calculation was carried out at a pressure of 1 bar by fixing $\mathrm{Fe}_{2} \mathrm{O}_{3}$ at $1 \mathrm{~mol}$ and $\mathrm{VO}_{2}$ at $2.2 \mathrm{~mol}$. The input $\mathrm{NH}_{3}$ mole fraction was given as $n_{\mathrm{NH} 3} /\left(n_{\mathrm{NH} 3}+n_{\text {Solid }}\right)$, where $n_{\text {Solid }}$ represents the input mole numbers of $\mathrm{Fe}_{2} \mathrm{O}_{3}$ and $\mathrm{VO}_{2}$. The results in Figure 2 show the absolute mole numbers of solid phases during the reaction process. It can be seen from Figure 2 that $\mathrm{Fe}_{2} \mathrm{O}_{3}$ undergoes the transformation process of forming Fe step by step. The $\mathrm{NH}_{3}$ 
fraction required for generating $\mathrm{Fe}$ is around 0.78 . However, the reduction and nitridation of $\mathrm{VO}_{2}$ to form $\mathrm{VN}$ required $\mathrm{NH}_{3}$ fractions to reach above 1, which was much higher than the formation of Fe. It can be seen from Equations (1) and (2) that, at $1273 \mathrm{~K}$, the $\Delta \mathrm{G}^{\Theta}$ of Fe generated by FeO reduction was far less than the $\Delta \mathrm{G}^{\Theta}$ needed for $\mathrm{VN}$ formation. From the perspective of thermodynamics, the reaction condition for $\mathrm{VN}$ generation was extremely harsh.

$$
\begin{gathered}
2 \mathrm{NH}_{3}+\mathrm{FeO}=\mathrm{Fe}+\mathrm{H}_{2} \mathrm{O}+\mathrm{N}_{2}+2 \mathrm{H}_{2} \Delta \mathrm{G}^{\Theta}=123.42-0.2405 \mathrm{~T}(\mathrm{KJ} / \mathrm{mol}) \\
2 \mathrm{NH}_{3}+\mathrm{V}_{2} \mathrm{O}_{3}=2 \mathrm{VN}+3 \mathrm{H}_{2} \mathrm{O} \Delta \mathrm{G}^{\Theta}=144.00-0.1452 \mathrm{~T}(\mathrm{KJ} / \mathrm{mol})
\end{gathered}
$$
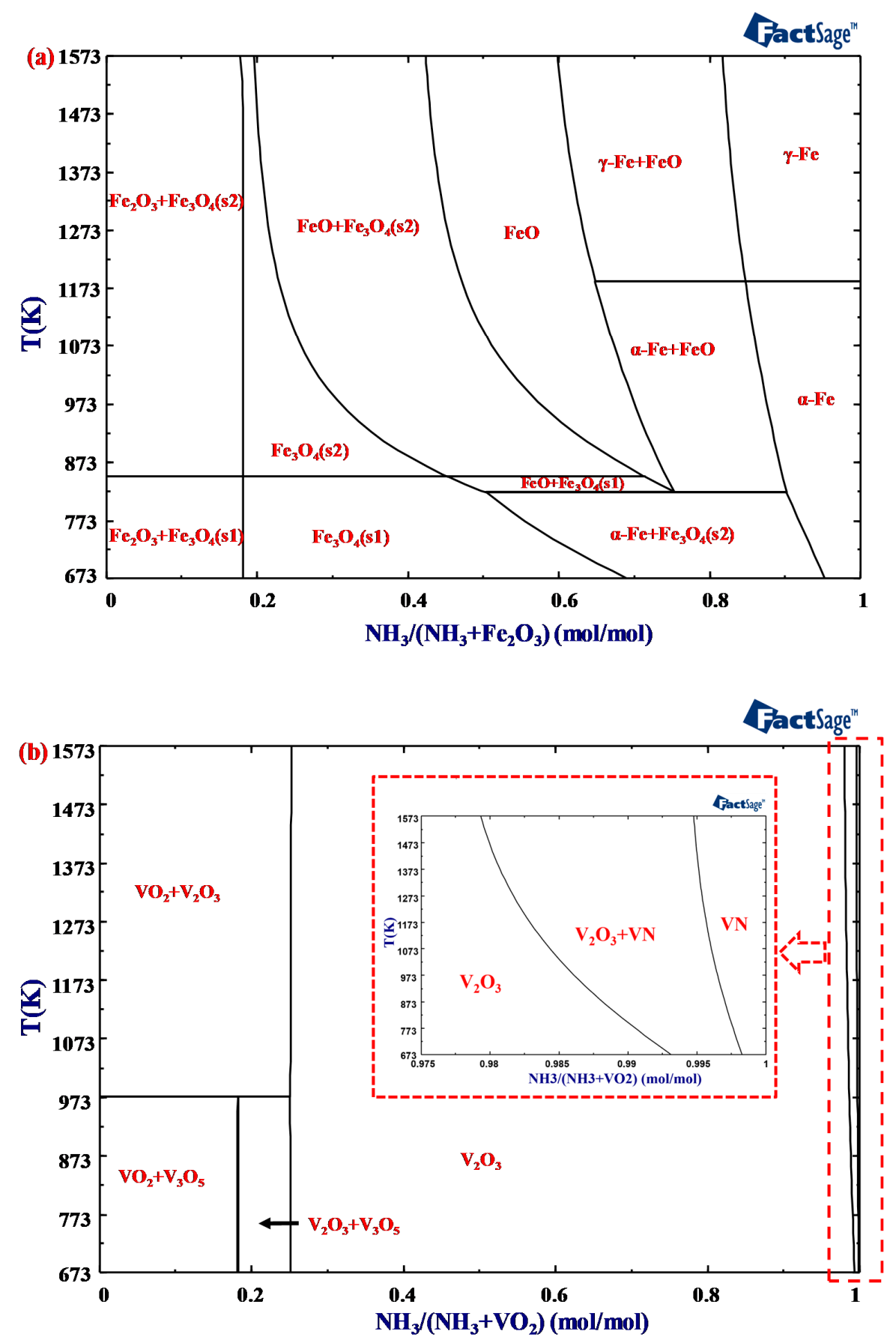

Figure 1. Predominant phase diagram of solid phases as functions of temperature and input $\mathrm{NH}_{3}$ fraction: (a) $\mathrm{NH}_{3}-\mathrm{Fe}_{2} \mathrm{O}_{3}$ system; (b) $\mathrm{NH}_{3}-\mathrm{VO}_{2}$ system. 


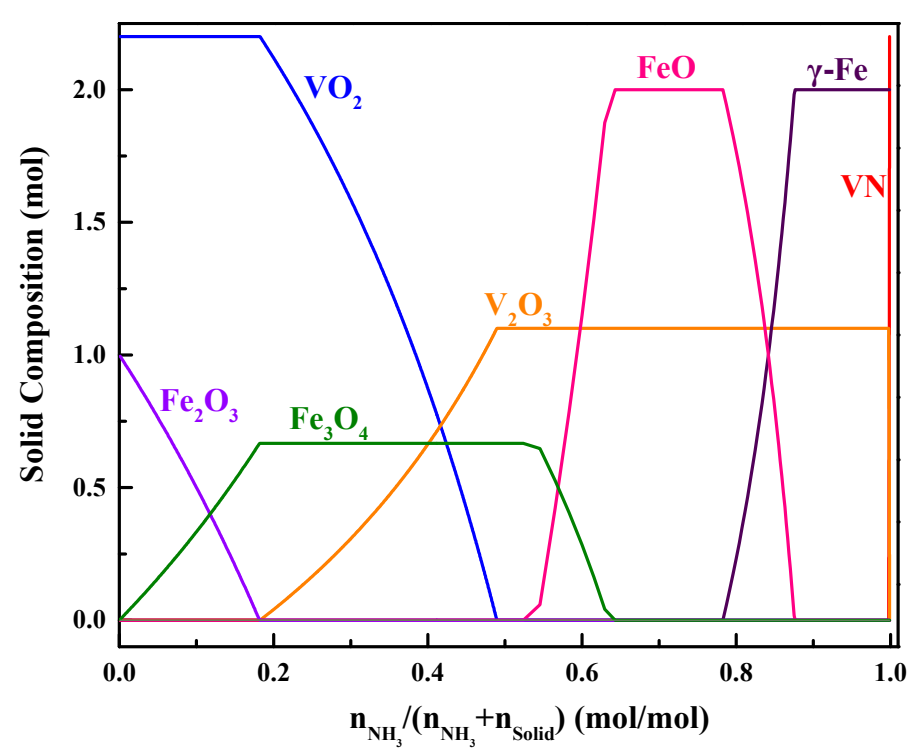

Figure 2. Equilibrium composition of solid products at $1273 \mathrm{~K}$ : $\mathrm{NH}_{3}-\mathrm{Fe}_{2} \mathrm{O}_{3}-\mathrm{VO}_{2}$ system (fixed 1.0 mol $\mathrm{Fe}_{2} \mathrm{O}_{3}$ and $2.2 \mathrm{~mol} \mathrm{VO}_{2}$ ).

\section{Results and Discussion}

\subsection{Phase Evolution during Reduction with Ammonia}

The phase compositions of the reduced and nitrided products were investigated, and the results are shown in Figure 3. Reduction roasting was conducted as a function of temperature $(4 \mathrm{~h})$ and duration (1273 K).
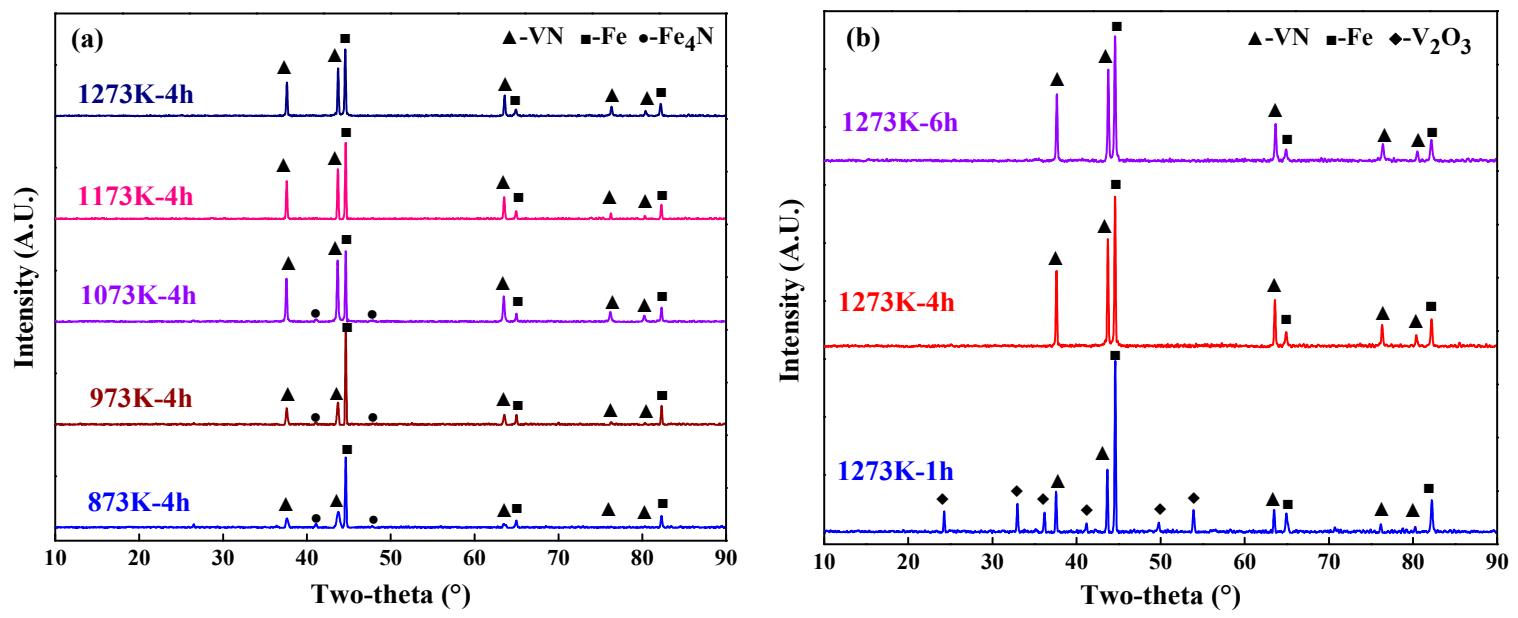

Figure 3. XRD patterns of products roasted for different durations at different temperatures: (a) 837-1273 K for $4 \mathrm{~h}$, (b) $1273 \mathrm{~K}$ for 1-6 h.

Figure 3a shows the phase composition with temperature in the range of $873-1273 \mathrm{~K}$ for $4 \mathrm{~h}$, respectively. As can be seen from the Figure $3 a$, three different phases, including VN, $\mathrm{Fe}$ and $\mathrm{Fe}_{4} \mathrm{~N}$, existed in the roasted samples. It indicated that $\mathrm{VO}_{2}$ and $\mathrm{Fe}_{2} \mathrm{O}_{3}$ have already been completely reduced or nitrided after $4 \mathrm{~h}$. When the reaction temperature was $873 \mathrm{~K}, \mathrm{VN}, \mathrm{Fe}$ and $\mathrm{Fe}_{4} \mathrm{~N}$ were present in the sample. The diffraction peaks were still assigned to $\mathrm{VN}, \mathrm{Fe}$ and $\mathrm{Fe}_{4} \mathrm{~N}$ with an increase of reaction temperature to $1073 \mathrm{~K}$. However, when the reaction temperature increased to $1173 \mathrm{~K}$, the diffraction peak of $\mathrm{Fe}_{4} \mathrm{~N}$ disappeared. This is because $\mathrm{Fe}_{4} \mathrm{~N}$ is unstable at high temperature and would decompose to Fe and $\mathrm{N}_{2}$. As can be seen from Equations (3) and (4), under standard conditions, the initial 
temperatures for reactions (3) and (4) are $595 \mathrm{~K}$ and $429 \mathrm{~K}$, respectively. It can be deduced that $\mathrm{Fe}_{4} \mathrm{~N}$ is easily converted to Fe under the experimental conditions. Meanwhile, as can be seen from Figure 3a, the relative strength of the diffraction peak of $\mathrm{Fe}_{4} \mathrm{~N}$ was relatively low, which also indicated that $\mathrm{Fe}_{4} \mathrm{~N}$ was unstable in ammonia atmosphere.

$$
\begin{gathered}
2 \mathrm{NH}_{3}+\mathrm{Fe}_{2} \mathrm{O}_{3}=1 / 2 \mathrm{Fe}_{4} \mathrm{~N}+3 \mathrm{H}_{2} \mathrm{O}+3 / 4 \mathrm{~N}_{2} \Delta \mathrm{G}^{\Theta}=172.01-0.2890 \mathrm{~T}(\mathrm{KJ} / \mathrm{mol}) \\
2 \mathrm{NH}_{3}+\mathrm{Fe}_{4} \mathrm{~N}=4 \mathrm{Fe}+3 / 2 \mathrm{~N}_{2}+3 \mathrm{H}_{2} \Delta \mathrm{G}^{\Theta}=123.68-0.2884 \mathrm{~T}(\mathrm{KJ} / \mathrm{mol})
\end{gathered}
$$

The phase transformation of $\mathrm{VO}_{2}$ and $\mathrm{Fe}_{2} \mathrm{O}_{3}$ as a function of duration is also compared. Figure $3 \mathrm{~b}$ shows the X-ray diffraction (XRD) patterns of samples roasted for different hours at $1273 \mathrm{~K}$. It was found that metallic Fe had already been formed after reacting for $1 \mathrm{~h}$. At the same time, $\mathrm{VO}_{2}$ has also been reduced. Both $\mathrm{V}_{2} \mathrm{O}_{3}$ and $\mathrm{VN}$ were observed after roasting for $1 \mathrm{~h}$, indicating $\mathrm{VO}_{2}$ was not completely converted to $\mathrm{VN}$. This is because $\mathrm{Fe}_{2} \mathrm{O}_{3}$ was easier to be reduced than $\mathrm{VO}_{2}$ under an ammonia atmosphere. The diffraction peak of $\mathrm{Fe}_{4} \mathrm{~N}$ was not present because the formed iron nitride was unstable at high temperature. As the duration increased to $4 \mathrm{~h}$ and $6 \mathrm{~h}$, only Fe and VN were observed. The results of phase transformation were in agreement with the thermodynamic analysis to some extent. As can be seen from Figure 2, $\mathrm{Fe}_{2} \mathrm{O}_{3}$ was initially reduced and metallic iron can coexist with $\mathrm{V}_{2} \mathrm{O}_{3}$. The phase of $\mathrm{V}_{2} \mathrm{O}_{3}$ will be finally reduced and nitride into $\mathrm{VN}$.

\subsection{Morphological Analysis}

The micromorphologies of the products obtained under different reaction conditions were investigated by scanning electron microscopy (SEM), and the results are plotted in Figure 4 . It can be seen from Figure $4 \mathrm{a}$ that when reducing at $1073 \mathrm{~K}$ for $4 \mathrm{~h}$, the powder particles of the reduced samples were still dispersive. The bright phase and the gray phase were mainly metallic Fe and VN, respectively, and a sintering phenomenon was negligible at $1073 \mathrm{~K}$. The morphology feature of VN was more obvious due to its face centered cubic crystal structure. By reducing at $1273 \mathrm{~K}$ for $6 \mathrm{~h}$, the powder particles of the samples accumulated to a larger size and showed an obvious sintering phenomenon, as shown in Figure $4 \mathrm{~b}$ and the energy dispersive spectrometer (EDS) results of points 3 and 4.

\subsection{Characterization of the Products}

In order to determine whether a prepared sample meets commercial application standards, the sample needs to be tested for oxygen and nitrogen contents. Table 1 shows the experimental results of nitrogen and oxygen measurements of FeV45N prepared under different conditions. It can be seen from Table 1 that as the reaction time and the reaction temperature increased, the $\mathrm{O}$ content of the product decreased and the nitrogen content increased, correspondingly. After reacting at 1273 $\mathrm{K}$ for $6 \mathrm{~h}$, the $\mathrm{O}$ content was as low as $0.25 \%$, and the $\mathrm{N}$ content was increased to $11.85 \%$, which meets the requirement of FeV45N that the elemental content of $\mathrm{N}$ is in the range of 9-12\% (National Standard of China, GB/T 30896-2014, Beijing, China). Meanwhile, no impurities are introduced into the powder, such as C, Al or S. Additionally, compared to the products obtained by solid or liquid nitridation methods, whose $\mathrm{N}$ contents were less than $10 \%$ and whose density was $4.0-4.5 \mathrm{~g} / \mathrm{cm}^{3}$, the $\mathrm{N}$ content and density in the present were obviously higher $[14,15]$. The FeVN alloy obtained by high-temperature synthesis method also had high density $\left(5.5-6.5 \mathrm{~g} / \mathrm{cm}^{3}\right)$, while the $\mathrm{N}$ content was in the range of $9-11 \%$ [16]. 

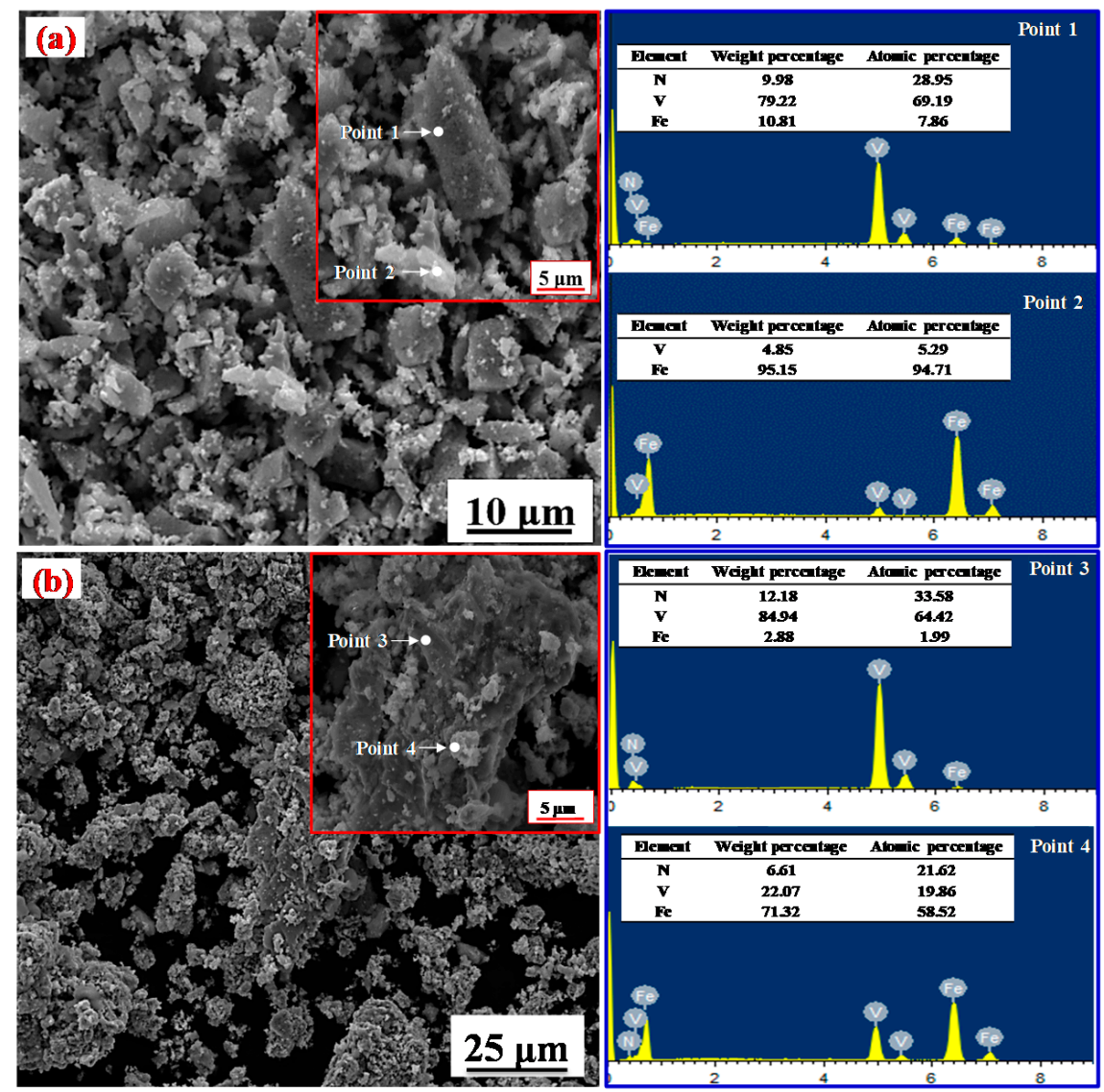

Figure 4. SEM micrographs and EDS patterns of products roasted at different temperatures: (a) $1073 \mathrm{~K}$ for $4 \mathrm{~h}$, (b) $1273 \mathrm{~K}$ for $6 \mathrm{~h}$.

Table 1. $\mathrm{O}$ and $\mathrm{N}$ contents of FeV45N.

\begin{tabular}{cccc}
\hline Temperature (K) & Reaction time (h) & O content (wt. \%) & N content (wt. \%) \\
\hline 1073 & 6 & 1.16 & 11.74 \\
1173 & 4 & 1.11 & 11.75 \\
1273 & 4 & 0.74 & 11.79 \\
1273 & 6 & 0.25 & 11.85 \\
\hline
\end{tabular}

\subsection{Microstructure of the Alloy after Sintering}

In order to increase the density of ferrovanadium nitride alloy, the obtained powders after reduction and nitridation were pressed into a bulk alloy (cylindrical briquette, $10 \mathrm{~mm}$ in diameter, $4 \mathrm{~mm}$ in thickness) by hot pressing (HP) at $1473 \mathrm{~K}$ for $1 \mathrm{~h}$ in vacuum. The density of the FeV45N alloy after sintering was determined as $5.92 \mathrm{~g} / \mathrm{cm}^{3}$, which was beneficial to increasing its utilization efficiency during the steel making process. The SEM micrograph and its corresponding area scanning results of the bulk alloy are presented in Figure 5. It can be seen that there were two main phases in the alloy, named metallic iron $(\mathrm{Fe})$ and vanadium nitride $(\mathrm{VN})$, respectively. There was an obvious boundary between the metallic iron and $\mathrm{VN}$ phases. The area scanning results also demonstrated that vanadium mainly existed in the form of $\mathrm{VN}$, because the region of vanadium overlapped with that of nitrogen. 

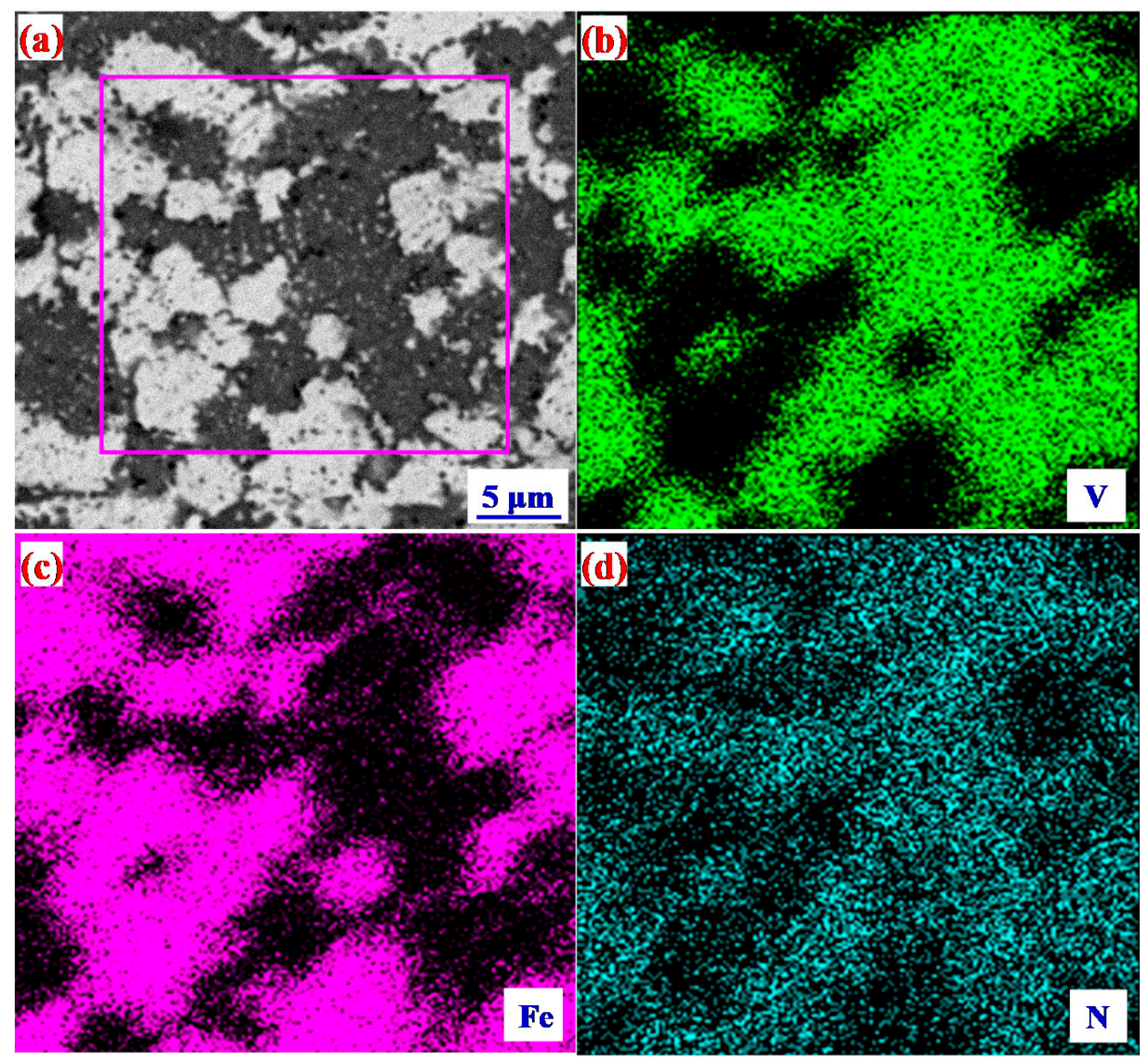

Figure 5. Microstructure of FeV45N alloy after sintering. (a) SEM micrograph: (b-d) the elemental distributions of $\mathrm{V}, \mathrm{Fe}$ and $\mathrm{N}$, respectively.

\subsection{Reaction Mechanism}

Although synthesizing vanadium nitride by ammonia reduction has been investigated $[30,35]$. The study by Vaidhyanathan et al. proved that high-purity $\mathrm{N}_{2}$ gas was less effective in the nitridation process than ammonia gas [30]. It is difficult to form vanadium nitride by reacting vanadium oxide with $\mathrm{N}_{2}$ and $\mathrm{H}_{2}$. Thermodynamically, $\mathrm{NH}_{3}$ would easily decompose to form $\mathrm{N}_{2}$ and $\mathrm{H}_{2}$ upon heating. However, the behavior of $\mathrm{NH}_{3}$ was rarely studied, and the components decomposed from ammonia gas were the actual reaction agents which would contact the raw materials. The actual $\mathrm{H}_{2}$ concentration in off-gas was detected by gas analyzer and the results are shown in Figure 6. It can be observed that the $\mathrm{H}_{2}$ concentration increased with an increase in temperature, and it remained almost unchanged after $1373 \mathrm{~K}$. The equilibrium $\mathrm{H}_{2}$ concentration increased from $12.5 \mathrm{vol} . \%$ to $53.5 \mathrm{vol} . \%$, which revealed that the pyrolysis of ammonia gas was enhanced by increasing the temperature. However, the experimental pyrolysis ratio was still less than the theoretical value, which can be reflected by $\ln K$. The theoretical and experimental values of $\ln K$ can be calculated according to Equations (6) and (7), respectively. The difference in the pyrolysis ratio may be attributed to the kinetic factors. Based on the above results, it can be deduced that ammonia gas was not completely decomposed, even at temperatures above $1373 \mathrm{~K}$, leaving the possibility of reacting by $\mathrm{NH}_{3}$. A wide range of molecular or radical $\mathrm{N}$-containing intermediates of ammonia pyrolysis, such as $\mathrm{N}, \mathrm{NH}, \mathrm{NH}_{2}$ and $\mathrm{N}_{2} \mathrm{H}_{\mathrm{x}}(\mathrm{x}=1-4)$ may also be formed for nitridation process [27].

$$
\begin{aligned}
2 \mathrm{NH}_{3}(\mathrm{~g}) \rightarrow & \mathrm{N}_{2}(\mathrm{~g})+3 \mathrm{H}_{2}(\mathrm{~g}) \Delta \mathrm{G}^{\Theta}=150340-230.6 \mathrm{~T}(\mathrm{~J} / \mathrm{mol}) \\
& \ln K=-\frac{\Delta G^{\Theta}}{R T}=-\frac{18082.75}{T}+27.74
\end{aligned}
$$




$$
\ln K=\ln \frac{P_{\mathrm{N}_{2}} \times P_{\mathrm{H}_{2}}^{3}}{P_{\mathrm{NH}_{3}}^{2}}
$$

where $K$ is the equilibrium constant; $P_{\mathrm{N} 2}, P_{\mathrm{H} 2}$ and $P_{\mathrm{NH} 3}$ are the partial pressures of $\mathrm{N}_{2}, \mathrm{H}_{2}$ and $\mathrm{NH}_{3}$, respectively.

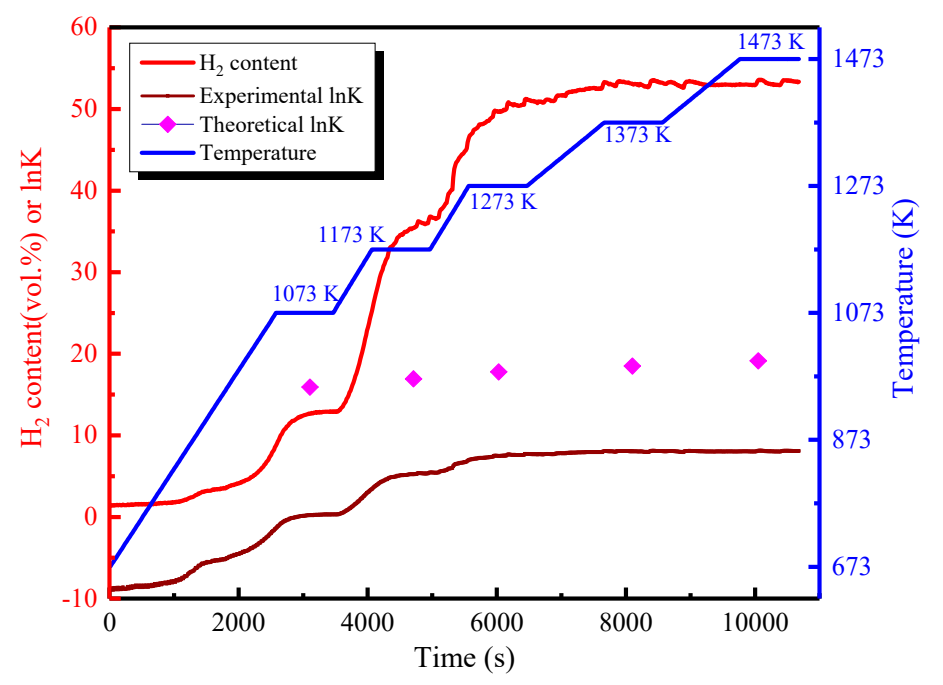

Figure 6. The pyrolysis of ammonia gas under different temperatures.

Thus, the reaction mechanisms can be described by the schematic diagram illustrated in Figure 7. $\mathrm{NH}_{3}$ may also react with $\mathrm{VO}_{2}$ and $\mathrm{Fe}_{2} \mathrm{O}_{3}$, even though it was easily decomposed during heating. When the temperature was lower than $1073 \mathrm{~K}, \mathrm{NH}_{3}$ reacted with $\mathrm{Fe}_{2} \mathrm{O}_{3}$ to form $\mathrm{Fe}$ and $\mathrm{Fe}_{4} \mathrm{~N}$ directly. The phase transformation during the entire reaction process proceeded in the following order: $\mathrm{Fe}_{2} \mathrm{O}_{3} \rightarrow \mathrm{Fe} \rightarrow \mathrm{Fe}_{4} \mathrm{~N}$. However, when the temperature was higher than $1073 \mathrm{~K}$, the transition path of $\mathrm{Fe}_{2} \mathrm{O}_{3}$ was $\mathrm{Fe}_{2} \mathrm{O}_{3} \rightarrow \mathrm{Fe}$. $\mathrm{Fe}_{4} \mathrm{~N}$ disappeared at higher temperatures. The difference may be ascribed to the kinetic factors. During the reaction process, the phase transformation of $\mathrm{VO}_{2}$ follows the order: $\mathrm{VO}_{2} \rightarrow \mathrm{V}_{2} \mathrm{O}_{3} \rightarrow \mathrm{VN}$. According to the above results, it can be concluded that ammonia gas is an effective reduction and nitridation agent for preparing $\mathrm{FeVN}$ alloy with iron and vanadium oxides as the raw material. Although FeV45N alloy has been prepared and the reaction mechanisms were preliminarily revealed in this paper, there are still lots of things that need to be studied further, such as the effect of precursor, gas composition, etc., on the preparation of FeVN alloy. Moreover, scaling up experiments are still on the way for future industrial production on the basis of the studied process. 


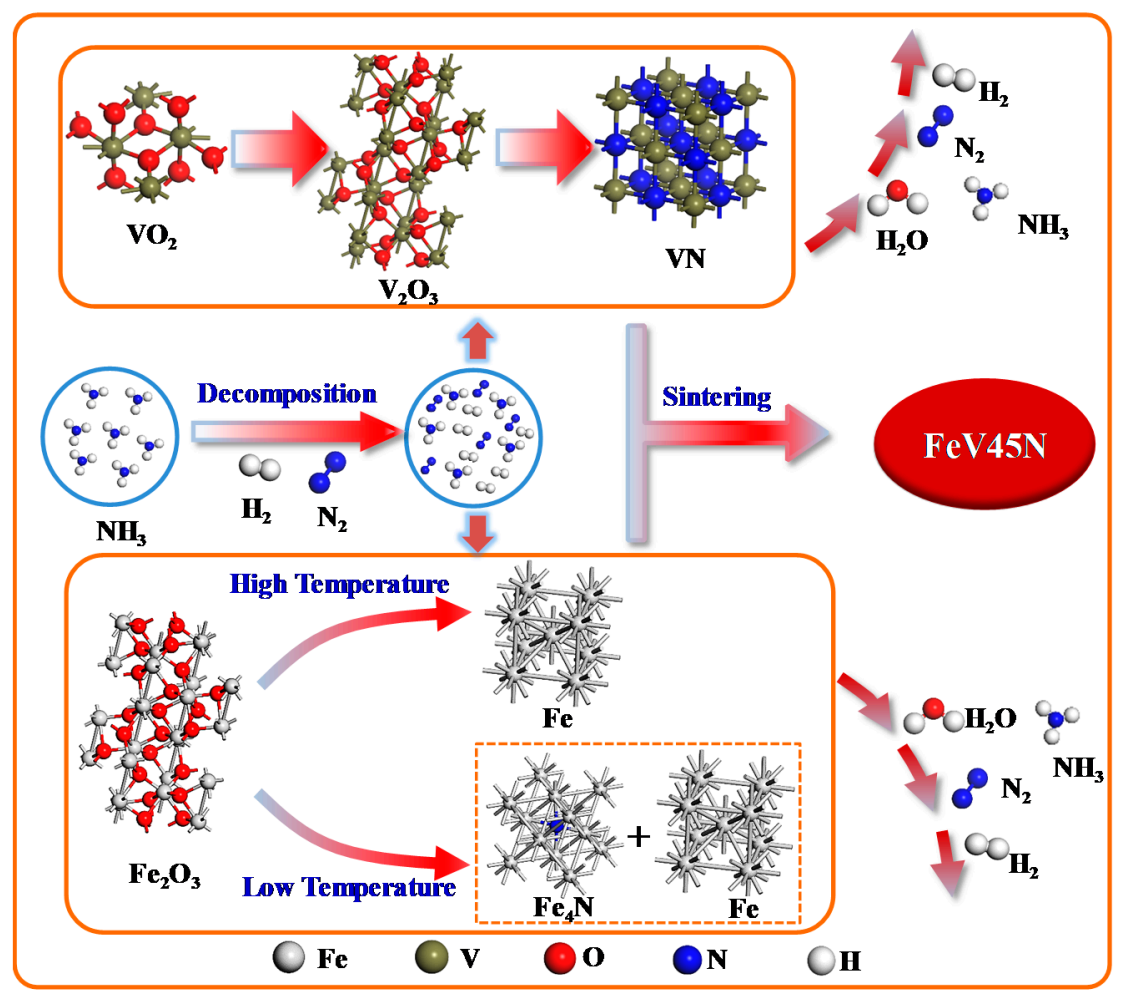

Figure 7. Schematic of the reaction mechanism of the formation of FeV45N.

\section{Conclusions}

This study describes the synthesis of FeV45N alloy by the reduction and nitridation of iron, and vanadium oxides mixture with ammonia gas. Thermodynamically, it was feasible to form metallic iron and vanadium nitride using ammonia gas as the reduction and nitridation agent. The experimental results indicated that the reaction temperature and time had significant effects on the reduction and nitridation process. With the increase of reaction temperature and time, the oxygen content was decreased gradually in the product. The maximum nitrogen and minimum oxygen content of FeV45N reached $11.85 \%$ and $0.25 \%$, respectively, by roasting at $1273 \mathrm{~K}$ for $6 \mathrm{~h}$. During the reaction process, the phase transformation of $\mathrm{VO}_{2}$ follows the order: $\mathrm{VO}_{2} \rightarrow \mathrm{V}_{2} \mathrm{O}_{3} \rightarrow \mathrm{VN}$. When the temperature was lower than $1073 \mathrm{~K}, \mathrm{NH}_{3}$ reacted with $\mathrm{Fe}_{2} \mathrm{O}_{3}$ to form $\mathrm{Fe}$ and $\mathrm{Fe}_{4} \mathrm{~N}$ directly. Fe could not form $\mathrm{Fe}_{4} \mathrm{~N}$ when the temperature was over $1073 \mathrm{~K}$. After sintering the composite powders at $1473 \mathrm{~K}$ for $1 \mathrm{~h}$, it is possible to obtain a bulk of FeV45N alloy with a density of up to $5.92 \mathrm{~g} / \mathrm{cm}^{3}$.

Author Contributions: Methodology, Y.L. and Z.Y.; software, Y.L. and Y.W.; validation, Y.L. and Y.W.; formal analysis, Y.L.; investigation, Y.L.; data curation, Y.L.; writing-original draft preparation, Y.L.; writing-review and editing, Z.Y. and X.L. All authors have read and agreed to the published version of the manuscript.

Funding: The authors wish to express their thanks to the National Key R\&D Program of China (2018YFC1900500) for the financial support of this research.

Conflicts of Interest: The authors declare no conflict of interest.

\section{References}

1. Baker, T.N. Processes, microstructure and properties of vanadium microalloyed steels. J. Mater. Sci. Technol. 2009, 25, 1083-1107. [CrossRef]

2. Vervynckt, S.; Verbeken, K.; Lopez, B.; Jonas, J.J. Modern HSLA steels and role of non-recrystallisation temperature. Int. Mater. Rev. 2012, 57, 187-207. [CrossRef]

3. Baker, T.N. Microalloyed steels. Ironmaking Steelmaking 2016, 43, 264-307. [CrossRef] 
4. Vdovin, K.; Pesin, A.; Feoktistov, N.; Gorlenko, D. Surface wear in hadfield steel castings DOPED with nitrided vanadium. Metals 2018, 8, 845. [CrossRef]

5. Li, H.Z.; Tong, W.P.; Cui, J.J.; Zhang, H.; Chen, L.Q.; Zuo, L. The influence of deep cryogenic treatment on the properties of high-vanadium alloy steel. Mater. Sci. Eng. A 2016, 662, 356-362. [CrossRef]

6. MacKenzie, M.; Craven, A.J.; Collins, C.L. Nanoanalysis of very fine VN precipitates in steel. Scr. Mater. 2006, 54, 1-5. [CrossRef]

7. Crooks, M.J.; Garratt, R.A.J.; Vander, S.J.B.; Owen, W.S. The isothermal austenite-ferrite transformation in some deformed vanadium steels. Metall. Trans. A 1982, 13, 1347-1353. [CrossRef]

8. Yücel, O.; Cinar, F.; Addemir, O.; Tekin, A. The preparation of ferroboron and ferrovanadium by aluminothermic reduction. High Temp. Mater. Processes (London) 1996, 15, 103-110.

9. Han, J.L.; Zhang, Y.M.; Liu, T.; Huang, J.; Xue, N.N.; Hu, P.C. Preparation of vanadium nitride using a thermally processed precursor with coating structure. Metals 2017, 7, 360. [CrossRef]

10. Zajac, S.; Siwecki, T.; Hutchinson, W.B.; Lagneborg, R. Strengthening mechanisms in vanadium microalloyed steels intended for long products. ISIJ Int. 1998, 38, 1130-1139. [CrossRef]

11. Cai, Z.; Mao, X.P.; Bao, S.Q.; Zhao, G.; Xu, Y.W. Influence of vanadium microalloying on deformation-induced pearlite transformation of eutectoid steel. Metals 2019, 9, 268. [CrossRef]

12. Grishchenko, S.G.; Matvienko, V.A.; Sarankin, V.A. Development and introduction of the production of nitrided ferrovanadium at zaporozhe ferroalloy plant. Stal 1982, 7, 42-44.

13. Franke, H.; Breuer, F.; Fuchs, A. Nitrogen-bearing sintering products and melted alloys. NEUE HUTTE 1966, 11, 604-606.

14. Krastev, D. Nitriding of ferroalloys. In Proceedings of the VI-th International Metallurgical Congress, Ohrid, Macedonia, 29 May-1 June 2014.

15. Liu, W.; Dong, K.; Zhu, R. Preparation of Nitrogenous Ferrovanadium by Gaseous Nitriding in the Liquid Phase Ferrovanadium. Proceeding of the 5th International Symposium on High-Temperature Metallurgical Processing, San Diego, CA, USA, 3 March 2014; pp. 185-192.

16. Ziatdinov, M.K.; Sha tokhin, I.M. Self-propagating high-temperature synthesis of ferrovanadium nitride for use in smelting high-strength low-alloy steels. Steel Transl. 2009, 39, 1005-1011. [CrossRef]

17. Pomarin, Y.M.; Grigorenko, G.M.; Lakomskiy, V.I. Solubility of nitrogen in iron alloys with vanadium and niobium. Russ. Metall. 1975, 5, 61-65.

18. Cheng, J.; Shen, H. Research on Nitrogen Solubility of Fe-Cr-Mn-V-N System Alloys in Liquid and Solid Phases. Trans. Indian Inst. Met. 2018, 71, 2433-2442. [CrossRef]

19. Wu, Y.D.; Zhang, G.H.; Chou, K.C. A novel process to synthesize high-quality ferrovanadium nitride. Metall. Mater. Trans. B 2016, 47, 3405-3412. [CrossRef]

20. Wu, Y.D.; Zhang, G.H.; Chou, K.C. Synthesis of high-quality FeV55N alloy by carbonitrothermic reduction of vanadium pentoxide-rerric oxide mixture. JOM 2017, 69, 676-1681. [CrossRef]

21. Claridge, J.B.; York, A.P.E.; Brungs, A.J.; Green, M.L.H. Study of the temperature-programmed reaction synthesis of early transition metal carbide and nitride catalyst materials from oxide precursors. Chem. Mater. 2000, 12, 132-142. [CrossRef]

22. Glushenkov, A.M.; Jurcakova, D.H.; Llewellyn, D.; Lu, G.Q.; Chen, Y. Structure and capacitive properties of porous nanocrystalline $\mathrm{VN}$ prepared by temperature-programmed ammonia reduction of $\mathrm{V}_{2} \mathrm{O}_{5}$. Chem. Mater. 2009, 22, 914-921. [CrossRef]

23. Dong, S.M.; Chen, X.; Gu, L.; Zhou, X.H.; Wang, H.B.; Liu, Z.H.; Han, P.X.; Yao, J.H.; Wang, L.; Cui, G.L.; et al. TiN/VN composites with core/shell structure for supercapacitors. Mater. Res. Bull. 2011, 46, 835-839. [CrossRef]

24. Colling, C.W.; Choi, J.G.; Thompson, L.T. Molybdenum nitride catalysts: $\mathrm{II}_{\text {. }} \mathrm{H}_{2}$ temperature programmed reduction and $\mathrm{NH}_{3}$ temperature programmed desorption. J. Catal. 1996, 160, 35-42. [CrossRef]

25. Galesic, I.; Reusch, U.; Angelkort, C.; Lewalter, H.; Berendes, A.; Schweda, E.; Kolbesen, B.O. Nitridation of vanadium in molecular nitrogen: a comparison of rapid thermal processing (RTP) and conventional furnace annealing. Vacuum 2001, 61, 479-484. [CrossRef]

26. Wexler, D.; Calka, A.; Mosbah, A.Y. Ti-TiN hard metals prepared by in situ formation of TiN during reactive ball milling of Ti in ammonia. J. Alloy. Compd. 2000, 309, 201-207. [CrossRef] 
27. Chen, H.Y.; Nambu, A.; Wen, W.; Graciani, J.; Zhong, Z.; Hanson, J.C.; Fujita, E.; Rodriguez, J.A. Reaction of $\mathrm{NH}_{3}$ with titania: $\mathrm{N}$-doping of the oxide and TiN formation. J. Phys. Chem. C 2007, 111, 1366-1372. [CrossRef]

28. Li, Y.G.; Gao, L.; Li, J.G.; Yan, D.S. Synthesis of nanocrystalline chromium nitride powders by direct nitridation of chromium oxide. J. Am. Ceram. Soc. 2002, 85, 1294-1296. [CrossRef]

29. Liu, Y.J.; Wang, Y.; Zhang, Y.; You, Z.X.; Lv, X.W. Mechanism on Reduction and Nitridation of Micron-Sized Titania with Ammonia Gas. J. Am. Ceram. Soc. 2020. [CrossRef]

30. Vaidhyanathan, B.; Rao, K.J. Synthesis of Ti, Ga, and V nitrides: Microwave-assisted carbothermal reduction and nitridation. Chem. Mater. 1997, 9, 1196-1200. [CrossRef]

31. Wu, Y.D.; Zhang, G.H.; Chou, K.C. Preparation of high-quality FeV55N using ammonia as a reductant and nitrogen source. JOM 2018, 70, 2493-2498. [CrossRef]

32. Barin, I.; Knacke, O.; Kubaschewski, O. Thermochemical Properties of Inorganic Substances; Springer: Berlin, Germany, 1977.

33. Stull, D.R.; Prophet, H. JANAF Thermochemical Tables; U.S. Department of Commerce: Washington, DC, USA, 1985.

34. Arabczyk, W.; Rafat, P. Studies of the kinetics of two parallel reactions: ammonia decomposition and nitriding of iron catalyst. J. Phys. Chem. A 2008, 113, 411-416. [CrossRef]

35. Qin, M.L.; Wu, H.Y.; Cao, Z.Q.; Zhang, D.Y.; Qu, X.H. A novel method to synthesize vanadium nitride nanopowders by ammonia reduction from combustion precursors. J. Alloy. Compd. 2019, 772, 808-813. [CrossRef]

(C) 2020 by the authors. Licensee MDPI, Basel, Switzerland. This article is an open access article distributed under the terms and conditions of the Creative Commons Attribution (CC BY) license (http://creativecommons.org/licenses/by/4.0/). 